\title{
USING FOLIAR APPLICATION OF Fe AND GA3 TO IMPROVE GROWTH OF TWO OLIVE CV. (Olea europaea) TRANSPLANTS
}

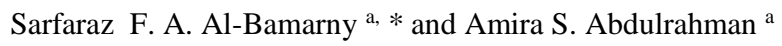 \\ a Dept. of Horticulture, college of Agriculture, University of Duhok, Iraq - (Sarfarazfatah@yahoo.com)
}

Received: Jun. 2018 / Accepted: Sept., 2018 / Published: Sept., 2018

https:/doi.org/10.25271/sjuoz.2018.6.3.510

\begin{abstract}
:
This investigation was carried out in the lath house of the nursery of Malta station/ Duhok. Kurdistan region, Iraq. During the growing season of 2017, to study the effect of the different concentrations of $\mathrm{Fe}\left(0,10\right.$ and $\left.20 \mathrm{mg} \mathrm{L}^{-1}\right)$ and $\mathrm{GA}_{3}(0,500$ and 1000 $\mathrm{mg} \mathrm{L}^{-1}$ ) on vegetative growth, roots length and leaves nutrients content of one-year-old of two olive cultivars (Nebali and Bashike) transplantings. The results appeared that Nebali cultivar significantly dominated in stem length $(\mathrm{cm})$, stem diameter $(\mathrm{mm})$, branch length $(\mathrm{cm})$, leaves number, root length $(\mathrm{cm}), \mathrm{N}(\%), \mathrm{K}(\%), \mathrm{P}(\%)$ and $\mathrm{Fe}\left(\mathrm{mg} \mathrm{L}^{-1}\right)$, Baeshike cultivar dominate in leaf area $(\mathrm{cm} 2)$, stem length $(\mathrm{cm})$, shoot root ratio, root length $(\mathrm{cm})$ and $\mathrm{K}(\%)$ were significantly increased with increase $\mathrm{GA}_{3}$ to $1000 \mathrm{mg} \mathrm{L}^{-1}$. Foliar application of $\mathrm{GA}_{3}$ at $500 \mathrm{mg} \mathrm{L}^{-1}$ significantly increased branch length $(\mathrm{cm})$ and $\mathrm{P}(\%)$. When the transplants treated with $10 \mathrm{mg}$ $\mathrm{L}^{-1} \mathrm{Fe}$ significantly effect on the Fe \% content but spray transplants with the $\mathrm{Fe}$ at $20 \mathrm{mg} \mathrm{L}^{-1}$ had significantly affected on stem diameter $(\mathrm{mm})$, leaves number root length $(\mathrm{cm})$ and $\mathrm{N}(\%)$. Most of the interactions (cultivar $\times \mathrm{Fe}$ and cultivar $\left.\times \mathrm{GA}_{3}\right)$ showed significant effects on the most studied characteristics.
\end{abstract}

KEYWORDS: Olive cultivars, $\mathrm{Fe}, \mathrm{GA}_{3}$, Growth characters.

\section{INTRODUCTION}

Olive (Olea europaea L.) has been known as "the fragrance of the soft gold" due to its high economic, social and cultural values. Nowadays, olive is the most extensively cultivated oleiferous tree species in the world, covering an area of 10 million of hectares (Yang et al., 2007).

Iron plays an important role in the activation of chlorophyll and in the synthesis of many heme proteins such as different cytochrome, which participate in different functions in the plant metabolism (Bhandari and Randhawa, 1985). $\mathrm{Fe}$ and $\mathrm{Cu}$ play key roles in several enzyme systems that contribute vital function in overall plant metabolisms (Romheld and Marschner, 1991). The olive tree requires small amounts of boron, iron zinc, manganese, copper and molybdenum. A deficiency in any of these elements can reduce growth and fruiting in the olive ( Kailis and Harris, 2007). Iron is an essential micronutrient for almost all living organisms because of it plays critical role in metabolic processes such as DNA synthesis, respiration, and photosynthesis. Further, many metabolic pathways are activated by iron, and it is a prosthetic group constituent of many enzymes. An imbalance between the solubility of iron in soil and the demand for iron by the plant are the primary causes of iron chlorosis (Gyana and Sunita, 2015). Iron is the third most limiting nutrient for plant growth and metabolism, primarily due to the low solubility of the oxidized ferric form an aerobic environments (Zuo and Zhang, 2011 and Samaranayke et al., 2012). Iron is involved in chlorophyll synthesis, and it is essential for the maintenance of chloroplast structure and function (Schmidt, 1993). Typically, approximately $80 \%$ of iron is found in photosynthetic cells where it is essential for the biosynthesis of cytochromes and other heme molecules, including chlorophyll, the electron transport system, and the construction of Fe-S clusters (Hansch and Mendel, 2009). Iron plays many essential roles in plant growth and development, including chlorophyll synthesis, thylakoid synthesis and chloroplast development. Iron is required at several steps in the biosynthetic pathways (Marschner, 1995).

Iron deficiency is one of the major abiotic stresses affecting fruit tree crops in the Mediterranean area. One of the most obvious characteristics of the plants affected by Fe deficiency is that their leaves become chlorotic (Morales et al., 1994). ElKassas et al., (1987) mentioned that mandarin seedlings when spraying by $\mathrm{Fe}$ at $250 \mathrm{mg} \mathrm{L}^{-1}$ led to increase of stem diameter. Shayal Alalam (2013) showed that the interaction between 2 ml. $\mathrm{L}^{-1}$ kelpak40 $+20 \mathrm{mg} \mathrm{Fe} . \mathrm{L}^{-1}$ of loquat seedlings significantly dominated in leaves number, seedling leaves area and leaves dry weight percentage.

Gibberellins is the second group of plant hormones that were discovered after auxins, biologically effective in stimulating cell division or elongation or both, they also have a role in the phenomenon of genetic dwarfism of plants and their influence in the process of formation of flowers and parthenocarpic fruits and the removal of seed dormancy and buds (Al-Khafaji, 2014).

GAs stimulates stem elongation by promoting cell elongation and cell division (Taiz and Zeiger, 2002). Gibberellins, especially gibberellic acid $\left(\mathrm{GA}_{3}\right)$ play an important role in the growth and development of plants. Gibberellins are classified as diverse group of plant hormones that enhance some physiological or biochemical pathways in plants. The use of $\mathrm{GA}_{3}$ for boosting the growth and vigor of various horticultural plants is very old known and well documented (Gul et al., 2006).

Gibberellins promote seed germination, stimulate stem elongation, leaf expansion, flowering, pollen and seed development and delay fruit ripening (Rosenvasser and Friedman, 2006). GA is responsible for cell elongation, rather than cell division (Francis and Sorrell, 2001). Al-Abbassy (2009) found that foliar spray with $\mathrm{GA}_{3}$ at $100 \mathrm{mg} \mathrm{L}^{-1}$ caused

\footnotetext{
* Corresponding author

This is an open access under a CC BY-NC-SA 4.0 license (https://creativecommons.org/licenses/by-nc-sa/4.0/)
} 
significant increase in height and diameter of the main stem, total chlorophyll in leaves and nitrogen and phosphorus percentage in apricot leaves. Hassan et al., (2010) recorded that, highest content of leaves $\mathrm{N}, \mathrm{K}, \mathrm{Fe}$ and $\mathrm{Zn}$ was in the plum trees treated with Aminofert at $0.25 \%+\mathrm{GA}_{3}$ at $20 \mathrm{mg} \mathrm{L}^{-1}$. Shayal Alalam (2009) noted that the peach trees when treated with $50 \mathrm{mg} \mathrm{L}^{-1} \mathrm{GA}_{3}$ caused significant increase in leaves $\mathrm{P}$ concentration, leaves number, trees leaf area and main stem diameter. Soest (2012) Found that the spray apple trees with gibberellic acid at $20 \mathrm{mg} \mathrm{L}^{-1}$ gave the highest leaf N, P, K and chlorophyll content. Al-Mousawi, (2013) Found that foliar spray with Gibberellic acid at $500 \mathrm{mg} \mathrm{L}^{-1}$ caused significant increase in length and diameter of the main stem, number of branches, leaves area, total chlorophyll in leaves and nitrogen, phosphorus, potassium and carbohydrates percentage in olive leaves. The main objective of this investigation, comparison between the response for two (Olea europaea L.) cultivars and improve the growth of both cultivars with add different concentration of $\mathrm{Fe}$ and $\mathrm{GA}_{3}$.

\section{MATERIALS AND METHODS}

This investigation was carried out in lath house at the nursery of the Malta station/ Duhok, Kurdistan region, Iraq. The investigation conducted on two olive cv. (Nebali and Bashike) transplants grown in boxes during 2017 season. The olive transplants were one year old. The study included two factors, first spray with $\mathrm{Fe}$ or $\mathrm{GA}_{3}$ were 5 treatments as follow:

1- Foliar sprays with distilled water only (control treatment for both $\mathrm{Fe}$ and $\mathrm{GA}_{3}$ ).

2- Spray with $10 \mathrm{mg} \mathrm{L}^{-1} \mathrm{Fe}$

3- Spray with $\mathrm{Fe}$ at $20 \mathrm{mg} \mathrm{L}^{-1}$

4- Spray with $\mathrm{GA}_{3}$ at $500 \mathrm{mg} \mathrm{L}^{-1}$

5- Spray with $\mathrm{GA}_{3}$ at $1000 \mathrm{mg} \mathrm{L}^{-1}$

The second factor included two olive cultivates. Transplanting were sprayed with above concentration three times 15 march, 15 April and 15 May 2017, with three levels of $\mathrm{Fe}(0,10$ and $\left.20 \mathrm{mg} \mathrm{L}^{-1}\right)$, and three levels of $\mathrm{GA}_{3}\left(0,500\right.$ and $\left.1000 \mathrm{mg} \mathrm{L}^{-1}\right)$, Foliar sprays were applied using a hand pressure sprayer.

The results were analyzed statistically and the comparison were made using Duncan' multiple range test at 5\% probability (AlRawi and Khalaf-Allah, 1980). All the data were tabulated and statistically analyzed with computer using (SAS system, 2000). The Measurements or parameters were:

1-Stem length $(\mathrm{cm})$ : It was measured at the end of investigation 10 November, 2017 using the measuring tape.

2- Stem diameter $(\mathrm{mm})$ : It was measured at $5 \mathrm{~cm}$ above soil surface using hand Vernier.

3- Branches length per Transplant $(\mathrm{cm})$ : The length of branches was calculated at the end of investigation.

4- Leaves number: The Leaves number was calculated at the end of field measurements.

5 - Leaf area $\left(\mathrm{cm}^{2}\right)$ : The average leaf area was determined by gravimetric method according to Drovnic et al., (1965).

6- Shoot / Root Ratio: This ratio was determined by weighting the shoots and roots of three transplants randomly chosen from each treatment (Goss, 1973).

7. Root length $(\mathrm{cm})$ : The root length was calculated at the end of field measurements.

8-Mineral Nutrient Contents of the Leaves:

a.) Macronutrient at content in plant includes the following elements (N.P.K).

1-Nitrogen (\%): It was determined by the Microkjelhdahl method.

2-Phosphorus (\%): It was determined by colorimetric method using Spectrophotometer pharmacia LKB method.

3- Potassium (\%): It was determined by the Flame photometer. b.) Micronutrient content $\mathrm{Fe}\left(\mathrm{mg} \mathrm{L}^{-1}\right)$ : The concentration was determined using Atomic absorption Spectrophotometer.

\section{RESULTS AND DISCUSSION}

3.1 Interaction effect of cultivars and spraying with $\mathrm{Fe}$ and GA3on some vegetative growth characters:

3.1.1 Stem Length (cm): Results in table (1) showed that transplants of Nebali cultivar had significantly higher stem length compared with the Baeshike cultivar. The transplants treated with $1000 \mathrm{mg} \mathrm{L}^{-1} \mathrm{GA}_{3}$ gave highest stem length, On the other hand the interaction between cultivars and concentration notice that the Baeshike transplants treated with $1000 \mathrm{mg} \mathrm{L}^{-1}$ $\mathrm{GA}_{3}$ showed maximum stem length which had significant effect with all other interaction treatment Nebali cultivar sprayed with same concentration of $\mathrm{GA}_{3}$. The increased in stem length with $\mathrm{GA}_{3}$ treatment was due to the role of this hormone in increasing nutrient absorption, causing cell multiplication and cell elongation in the cambium tissue of intermodal region therefore increased length of the transplanting (Shanmugavelu, 1966). The results are also agreed with results of Harshavardhan and Rajasekhar (2012) for jackfruit and Vasantha et al., (2014) in tamarind. These results compatible with other studies performed by Steven, (1994) and Al-Kafaji and Muslat, (1995) who mentioned that the increase in growth of treated plants attributed to growth improvement of $\mathrm{GA}_{3}$ treated plants to the influence of $\mathrm{GA}_{3}$ on cell wall and cell cytoplasm. They found that $\mathrm{GA}_{3}$ highly increased cell size and cell number which finally reflected on tissue size, and they referred that Osmotic of cell solution to the impact of $\mathrm{GA}_{3}$ on mRNA transcriptions was responsible for enzyme synthesis, especially those involved in chlorophyll synthesis.

3.1.2 Stem Diameter (mm): Table 1 showed that the nebali cultivar has the highest value of stem diameter when the transplants sprayed with the $\mathrm{Fe}$ at $20 \mathrm{mg} \mathrm{L}^{-1}$ as compared with the other concentrations of $\mathrm{Fe}$ and $\mathrm{GA}_{3}$. This result may be due to effect of iron fertilizer on accelerating metabolism reactions as well as stimulating enzymes (Yousefzadeh and Sabaghnia, 2016). Fe is a cofactor approximately for more than hundred enzymes that catalyze physiological processes (Brittenham, 1994).

3.1.3 Branch length (cm): The branches length was significantly influenced by cultivars. Nebali transplants branches length was longer than Baeshike cultivar. Transplant treated with $500 \mathrm{mg} \mathrm{L}^{-1} \mathrm{GA}_{3}$ gave a significant value (table 1), about the interaction between cultivar and concentration the Nebali cultivar treated with $500 \mathrm{mg} \mathrm{L}^{-1}$. $\mathrm{GA}_{3}$ recorded the highest significant value compared with other interaction treatments. El-Shenawy (2005) found that $\mathrm{GA}_{3}$ or $\mathrm{KNO}_{3}$ treatments either alone or combined with inflorescences thinning stimulated tree growth of mango cv. Kiett. The gibberellic acid may lead to increase side buds open in many plant species, which produce branches and leaves, as well as that $\mathrm{GA}_{3}$ retards aging and fallen leaves, leading to increase the number of remaining leaves on the trees until the end of the season (Al-Khafaji, 2014).

3.1.4 Leaves number: No significant difference was noticed between the two cultivars. Foliar spray of $500 \mathrm{mg} \mathrm{L}^{-1} \mathrm{GA}_{3}$ significantly increased leaves number in comparison with the untreated transplants. The highest leaves number was recorded for Baeshike cultivar treated with $500 \mathrm{mgL}^{-1} \mathrm{GA}_{3}$. It might be due to activity of $\mathrm{GA}_{3}$ at the apical meristem resulting in more synthesis of nucleoprotein responsible for increasing leaf initiation and leaf area (Sen and Ghunti, 1976). It may be also due to $\mathrm{GA}_{3}$ which induced vigorous growth by more number of branches which expose to sunshine by the plants to produce more number of leaves. This is in line with the results of Shaban (2010) in mango and Anjanaw et al., (2013) in papaya. 
Table 1. Effects of Foliar Spray of Fe and $\mathrm{GA}_{3}$ on some vegetative growth characters of two Olive cv. (Olea europaea) transplants.

\begin{tabular}{|c|c|c|c|c|}
\hline \multirow[b]{2}{*}{ Cultivar } & \multicolumn{4}{|c|}{ Parameters } \\
\hline & $\begin{array}{c}\text { Stem } \\
\text { length } \\
\text { (cm) }\end{array}$ & $\begin{array}{c}\text { Stem } \\
\text { diameter } \\
(\mathbf{m m})\end{array}$ & $\begin{array}{c}\text { Branch } \\
\text { length } \\
(\mathrm{cm})\end{array}$ & $\begin{array}{c}\text { Leaves } \\
\text { number (leaf/ } \\
\text { transplant) }\end{array}$ \\
\hline Baeshike & $63.47 \mathrm{~b}$ & $9.20 \mathrm{~b}$ & $35.27 \mathrm{~b}$ & $319.73 \mathrm{a}$ \\
\hline Nebali & $68.40 \mathrm{a}$ & $9.69 \mathrm{a}$ & $36.07 \mathrm{a}$ & $302.73 \mathrm{a}$ \\
\hline$\left(\mathrm{mg} \mathrm{L}^{-1}\right)$ & \multicolumn{4}{|c|}{ Concentration } \\
\hline Control 0 & $49.33 \mathrm{~d}$ & $6.52 \mathrm{~d}$ & $25.50 \mathrm{~d}$ & $166.00 \mathrm{~d}$ \\
\hline Fe 10 & $63.17 \mathrm{c}$ & $10.19 b$ & $37.83 \mathrm{~b}$ & $236.67 \mathrm{c}$ \\
\hline $\mathrm{Fe} 20$ & $67.67 \mathrm{~b}$ & $11.75 \mathrm{a}$ & $38.33 \mathrm{~b}$ & $393.17 \mathrm{a}$ \\
\hline GA3 500 & $66.50 \mathrm{~b}$ & $8.39 \mathrm{~d}$ & $40.67 \mathrm{a}$ & $422.83 \mathrm{a}$ \\
\hline GA31000 & $83.00 \mathrm{a}$ & $10.37 \mathrm{c}$ & $36.00 \mathrm{c}$ & $337.50 \mathrm{~b}$ \\
\hline$\left(\mathrm{mg} \mathrm{L}^{-1}\right)$ & \multicolumn{4}{|c|}{ Cultivar $\times$ Concentration } \\
\hline $\mathrm{B}^{*} \times$ Control 0 & $53.33 \mathrm{e}$ & $6.37 \mathrm{ed}$ & $24.67 \mathrm{e}$ & 190.33 ef \\
\hline $\mathrm{B}^{*} \times \mathrm{Fe} 10$ & $63.33 \mathrm{c}$ & $9.38 \mathrm{c}$ & $37.67 \mathrm{c}$ & $258.00 \mathrm{~d}$ \\
\hline $\mathrm{B}^{*} \times \mathrm{Fe} 20$ & $57.67 \mathrm{~d}$ & $\begin{array}{l}10.18 \\
b c\end{array}$ & $41.67 \mathrm{~b}$ & $348.33 \mathrm{bc}$ \\
\hline $\mathrm{B}^{*} \times \mathrm{GA} 3500$ & $58.67 \mathrm{~d}$ & $9.38 \mathrm{c}$ & $34.00 \mathrm{~d}$ & $447.00 \mathrm{a}$ \\
\hline $\mathrm{B}^{*} \times \mathrm{GA} 31000$ & $84.33 \mathrm{a}$ & $10.31 b c$ & $38.33 \mathrm{c}$ & $355.00 \mathrm{bc}$ \\
\hline $\mathrm{N}^{* *} \times$ Control 0 & $45.33 \mathrm{f}$ & $6.30 \mathrm{e}$ & $26.33 \mathrm{e}$ & $141.67 \mathrm{f}$ \\
\hline $\mathrm{N}^{* *} \times \mathrm{Fe} 10$ & $63.00 \mathrm{c}$ & $11 \mathrm{~b}$ & $38.00 \mathrm{c}$ & $215.33 \mathrm{de}$ \\
\hline $\mathrm{N}^{* *} \times \mathrm{Fe} 20$ & $77.67 \mathrm{~b}$ & $13.32 \mathrm{a}$ & $35.00 \mathrm{~d}$ & $438.00 \mathrm{a}$ \\
\hline $\mathrm{N}^{* *} \times \mathrm{GA} 3500$ & $74.33 \mathrm{~b}$ & $7.39 \mathrm{~d}$ & $47.33 \mathrm{a}$ & $398.67 \mathrm{ab}$ \\
\hline $\mathrm{N}^{* *} \times \mathrm{GA} 31000$ & $81.67 \mathrm{a}$ & $10.34 \mathrm{~b}$ & $33.67 \mathrm{~d}$ & $320.00 \mathrm{c}$ \\
\hline
\end{tabular}

Means for each character separately (the same column) for both factors and their interactions having the same letter or letters are not different significantly according to Duncan's multiple range test at 5\% level. $\mathrm{B}^{*}$ : mean Baeshike; $\mathrm{N}^{* *}$ : mean Nebali

3.1.5 Leaf area $\left(\mathrm{Cm}^{2}\right)$ : Table 2 notice that the transplants of Baeshike cultivar had significantly higher leaf area than transplants of Nebali cultivar. The transplant when treated with $1000 \mathrm{mg} \mathrm{L}^{-1} \mathrm{GA}_{3}$ significantly had a large leaf area. For the interaction between the cultivar and concentration recorded that Baeshike cultivars transplants that treated with the 1000 $\mathrm{mg} \mathrm{L}^{-1} \mathrm{GA}_{3}$ gave highest significant value in comparing with the other interaction treatments.

3.1.6 Shoot -root ratio: Table (2) showed that significant differences in shoot root ratio between the cultivars show that Baeshike cultivar significantly increased when compared with Nebali transplant. The transplants when treated with the 1000 $\mathrm{mg} \mathrm{L}^{-1} \mathrm{GA}_{3}$ gave the higher value (14.82) when compared with other concentration. The Baeshike cultivar when treated with the $1000 \mathrm{mg} \mathrm{L}^{-1} \mathrm{GA}_{3}$ had superior average shoot root ratio compared with the other concentration. The increase of shoot root ratio was closely correlated with the change in activities of sugar metabolizing enzymes induced by GA application (Ramezani and Shekafandeh, 2009). The improvement occurred in shoot root ratio in transplanting due to supplying transplants with $\mathrm{GA}_{3}$ could be attributed to its role in increasing cell elongation (Abd El-Moneim et al., 2007). Marschner (1986) indicated that application of $\mathrm{GA}_{3}$ on higher plants caused elongation in the primary cells of young tissues and growth centers. The present results may be attributed to simulative influence of this bio-regulator on cell extension and cell division.

3.2 Interaction effect of cultivars and spraying with $\mathrm{Fe}$ and GA $_{3}$ on root length $(\mathbf{c m})$ : Baeshike cultivar significantly had higher root length compared with root length of Nebali transplant. The root length increased when sprayed with the $\mathrm{GA}_{3}$ at $1000 \mathrm{mg} \mathrm{L}^{-1}$ and no significant with the transplanted treated with the $20 \mathrm{mg} \mathrm{L}^{-1} \mathrm{Fe}$ and $500 \mathrm{mg} \mathrm{L}^{-1} \mathrm{GA}_{3}$. The interaction between the cultivars and concentrations showed that the Baeshike cultivar when treated with the $20 \mathrm{mg} \mathrm{L}^{-1} \mathrm{Fe}$ gave the highest significant value in comparison with the other Interaction treatments. This could be due to the iron role as an important component of proteins in cells, events such as respiration and cell division (Zocchi et al., 2007).

Table 2. effects of foliar spray of $\mathrm{Fe}$ and $\mathrm{GA}_{3}$ on some growth characters of two Olive cv. (Olea europaea) transplants.

\begin{tabular}{|c|c|c|c|}
\hline & \multicolumn{3}{|c|}{ Parameters } \\
\hline Cultivar & $\begin{array}{l}\text { Leaf area } \\
\left(\mathrm{cm}^{2}\right)\end{array}$ & $\begin{array}{l}\text { Shoot- root } \\
\text { ratio }\end{array}$ & $\begin{array}{c}\text { Root } \\
\text { length } \\
(\mathrm{cm})\end{array}$ \\
\hline Baeshike & $11.62 \mathrm{a}$ & $2.15 \mathrm{a}$ & $33.27 \mathrm{a}$ \\
\hline Nebali & $9.65 \mathrm{~b}$ & $1.87 \mathrm{~b}$ & $28.60 \mathrm{~b}$ \\
\hline$\left(\mathrm{mg} \mathrm{L}^{-1}\right)$ & \multicolumn{3}{|c|}{ Concentration } \\
\hline Control 0 & $5.35 \mathrm{e}$ & $1.62 \mathrm{~d}$ & $21.67 \mathrm{c}$ \\
\hline $\mathrm{Fe} 10$ & $13.20 \mathrm{~b}$ & $1.93 \mathrm{c}$ & $31.17 \mathrm{~b}$ \\
\hline $\mathrm{Fe} 20$ & $9.28 \mathrm{~d}$ & $1.76 \mathrm{~d}$ & $34.83 \mathrm{a}$ \\
\hline $\mathrm{GA}_{3} 500$ & $10.52 \mathrm{c}$ & $2.29 \mathrm{~b}$ & $33.33 \mathrm{ab}$ \\
\hline $\mathrm{GA}_{3} 1000$ & $14.82 \mathrm{a}$ & $2.45 \mathrm{a}$ & $33.67 \mathrm{a}$ \\
\hline$\left(\mathrm{mg} \mathrm{L}^{-1}\right)$ & \multicolumn{3}{|c|}{ Cultivar $\times$ Concentration } \\
\hline $\mathrm{B} \times$ Control 0 & $4.40 \mathrm{f}$ & $1.68 \mathrm{ef}$ & $25.67 \mathrm{f}$ \\
\hline $\mathrm{B} \times \mathrm{Fe} 10$ & $14.48 \mathrm{~b}$ & $2.49 \mathrm{~b}$ & $35.67 \mathrm{bc}$ \\
\hline $\mathrm{B} \times \mathrm{Fe} 20$ & $9.90 \mathrm{~d}$ & $1.66 \mathrm{ef}$ & $39.33 \mathrm{a}$ \\
\hline $\mathrm{B} \times \mathrm{GA}_{3} 500$ & $12.19 \mathrm{c}$ & $2.08 \mathrm{c}$ & $34.33 \mathrm{~b}-\mathrm{d}$ \\
\hline $\mathrm{B} \times \mathrm{GA}_{3} 1000$ & $17.15 \mathrm{a}$ & $2.84 \mathrm{a}$ & $31.33 \mathrm{de}$ \\
\hline $\mathrm{N}^{* *} \times$ Control 0 & $6.30 \mathrm{e}$ & $1.55 \mathrm{fg}$ & $17.67 \mathrm{~g}$ \\
\hline $\mathrm{N}^{* *} \times \mathrm{Fe} 10$ & $11.93 \mathrm{c}$ & $1.36 \mathrm{~g}$ & $26.67 \mathrm{f}$ \\
\hline $\mathrm{N} * * \times \mathrm{Fe} 20$ & $8.67 \mathrm{~d}$ & $1.86 \mathrm{de}$ & $30.33 \mathrm{e}$ \\
\hline $\mathrm{N} * * \times \mathrm{GA}_{3} 500$ & $8.85 \mathrm{~d}$ & $2.49 \mathrm{~b}$ & $32.33 \mathrm{c}-\mathrm{e}$ \\
\hline $\mathrm{N} * * \times \mathrm{GA}_{3} 1000$ & $12.49 \mathrm{~b}$ & $2.06 \mathrm{~cd}$ & $36.00 \mathrm{~b}$ \\
\hline
\end{tabular}

Means for each character separately (the same column) for both factors and their interactions having the same letter or letters are not different significantly according to Duncan's multiple range test at $5 \%$ level. $\mathrm{B}^{*}$ : mean Baeshike; $\mathrm{N}^{* *}$ : mean Nebali.

\subsection{Interaction effect of cultivars and spraying with $\mathrm{Fe}$ and GA3 on nutrients elements:}

Table 3 shows Nitrogen, Potassium and phosphor percentage in leaves was significantly influenced by cultivars. Nebali cultivar leaves had significantly more concentration of NPK than the leaves of Baeshike cultivar while there was no significant difference between the two cultivars in leaf iron content. The transplant when treated with the $20 \mathrm{mg} \mathrm{L}^{-1} \mathrm{Fe}$ gave highest nitrogen value when compared with other concentration $(1.6 \%)$, while when the transplants treated with $1000 \mathrm{mg} \mathrm{L}^{-1} \mathrm{GA}_{3}$ gave the highest value of potassium when compare with other concentrations. the transplants treated with at $500 \mathrm{mg} \mathrm{L}^{-1} \mathrm{GA}_{3}$ gave the highest percent of phosphor $(0.103 \%)$ when compare to other treatments. On other hand the transplants when treated with the $\mathrm{Fe}$ at $10 \mathrm{mg} \mathrm{L}^{-1}$ gave the highest value of Fe content in leaves (143.53). The interaction between the cultivars and concentration notice that the Baeshike cultivar treated with $\mathrm{GA}_{3}$ at $1000 \mathrm{mg} \mathrm{L}^{-1}$ gave the highest percentage of $(\mathrm{N}, \mathrm{K}$ and $\mathrm{P} \%$ ) while the Nebali cultivar when treated with $\mathrm{Fe}$ at $10 \mathrm{mg} \mathrm{L}^{-1}$ gave the highest value (154.83 $\mathrm{mg} \mathrm{L}^{-1}$ ) when compared with the other concentrations. That's back to the role of gibberellic acid in the division and cell elongation (Gindia, 2003), which may lead to increased absorption of some nutrients from the soil, including nitrogen potassium concentrations in leaves. Generally, these results are in harmony with those reported by (Desouky, 2016) on olive trees, (Al-Abbassy, 2009 and Al-Hamadany, 2009) when they worked on apricot trees. However, Homo brass inolide, increased nitrogen fixation and enhance soluble protein content and photosynthesis (Clouse and Sasse, 1996). 
Table 3. Effects of foliar spray of $\mathrm{Fe}$ and $\mathrm{GA}_{3}$ on the leaves minerals content from elements (N,P and $\mathrm{K} \%)$ and $\mathrm{Fe}\left(\mathrm{mg} \mathrm{L}^{-1}\right)$ of two Olive cv. (Olea europaea) transplants.

\begin{tabular}{|c|c|c|c|c|}
\hline \multirow[b]{2}{*}{ Cultivar } & \multicolumn{4}{|c|}{ Parameters } \\
\hline & $\begin{array}{l}\text { Leaves } \\
\mathrm{N}(\%)\end{array}$ & $\begin{array}{l}\text { Leaves } \\
\mathrm{K}(\%)\end{array}$ & $\begin{array}{c}\text { Leaves } \\
\mathrm{P}(\%)\end{array}$ & $\begin{array}{l}\text { Leaves } \\
\mathrm{Fe}\left(\mathrm{mg} \mathrm{L}^{-1}\right)\end{array}$ \\
\hline Baeshike & $1.30 \mathrm{~b}$ & $1.01 \mathrm{~b}$ & $0.090 \mathrm{~b}$ & $120.94 \mathrm{a}$ \\
\hline Nebali & $1.55 \mathrm{a}$ & $1.04 \mathrm{a}$ & $0.100 \mathrm{a}$ & $118.96 \mathrm{a}$ \\
\hline$\left(\mathrm{mg} \mathrm{L}^{-1}\right)$ & \multicolumn{4}{|c|}{ Concentration } \\
\hline Control 0 & $1.34 \mathrm{~d}$ & $0.80 \mathrm{c}$ & $0.081 \mathrm{c}$ & $90.38 \mathrm{e}$ \\
\hline Fe 10 & $1.27 \mathrm{e}$ & $1.01 \mathrm{~b}$ & $0.086 \mathrm{c}$ & $143.53 \mathrm{a}$ \\
\hline $\mathrm{Fe} 20$ & $1.60 \mathrm{a}$ & $1.06 \mathrm{~b}$ & $0.093 \mathrm{~b}$ & $135.53 \mathrm{~b}$ \\
\hline $\mathrm{GA}_{3} 500$ & $1.39 \mathrm{c}$ & $1.01 \mathrm{~b}$ & $0.103 \mathrm{a}$ & $106.72 \mathrm{~d}$ \\
\hline $\mathrm{GA}_{3} 1000$ & $1.53 \mathrm{~b}$ & $1.23 \mathrm{a}$ & $\begin{array}{l}0.093 \\
a b\end{array}$ & $123.58 \mathrm{c}$ \\
\hline$\left(\mathrm{mg} \mathrm{L}^{-1}\right)$ & \multicolumn{4}{|c|}{ Cultivar $\times$ Concentration } \\
\hline B* $\times$ Control 0 & $4.40 \mathrm{f}$ & $0.75 \mathrm{~g}$ & $0.080 \mathrm{~d}$ & $109.77 \mathrm{~d}$ \\
\hline $\mathrm{B} * \times \mathrm{Fe} 10$ & $14.48 \mathrm{~b}$ & $0.94 \mathrm{e}$ & $0.083 \mathrm{~cd}$ & $132.23 \mathrm{c}$ \\
\hline $\mathrm{B} * \times \mathrm{Fe} 20$ & $9.90 \mathrm{~d}$ & $1.10 \mathrm{~b}$ & $0.090 \mathrm{~cd}$ & $126.83 \mathrm{c}$ \\
\hline $\mathrm{B} * \times \mathrm{GA}_{3} 500$ & $12.19 \mathrm{c}$ & $1.02 \mathrm{~cd}$ & $0.093 \mathrm{bc}$ & $130.43 \mathrm{c}$ \\
\hline $\mathrm{B} * \times \mathrm{GA}_{3} 1000$ & $17.15 \mathrm{a}$ & $1.24 \mathrm{a}$ & $0.107 \mathrm{a}$ & $105.43 \mathrm{~d}$ \\
\hline $\mathrm{N}^{* *} \times$ Control 0 & $6.30 \mathrm{e}$ & $0.86 \mathrm{f}$ & $0.083 \mathrm{~cd}$ & $71.00 \mathrm{f}$ \\
\hline $\mathrm{N} * * \times \mathrm{Fe} 10$ & $11.93 \mathrm{c}$ & $1.08 \mathrm{bc}$ & $0.093 \mathrm{bc}$ & $154.83 \mathrm{a}$ \\
\hline $\mathrm{N} \times \mathrm{Fe} 20$ & $8.67 \mathrm{~d}$ & $1.03 \mathrm{~cd}$ & $0.103 \mathrm{a}$ & $144.23 \mathrm{~b}$ \\
\hline $\mathrm{N}^{* *} \times \mathrm{GA}_{3} 500$ & $8.85 \mathrm{~d}$ & $1.01 \mathrm{de}$ & $0.100 \mathrm{ab}$ & $83.00 \mathrm{e}$ \\
\hline $\mathrm{N}^{* *} \times \mathrm{GA}_{3} 1000$ & $12.49 \mathrm{c}$ & $1.22 \mathrm{a}$ & $0.100 \mathrm{ab}$ & $141.73 b$ \\
\hline
\end{tabular}

Means for each character separately (the same column) for both factors and their interactions having the same letter or letters are not different significantly according to Duncan's multiple range test at $5 \%$ level. $\mathrm{B}^{*}$ : mean Baeshike; $\mathrm{N}^{* *}$ : mean Nebali

\section{REFERENCES}

Abd El-Moneim, E. A. A., Abd El Migeed, M. M. M. and Ismail. O. M. M. (2007). GA $A_{3}$ and Zinc Sprays for Improving Yield and Fruit Quality of Washington Navel Orange Trees Grown under Sandy Soil Conditions. J. Agric. And Bio Sci., Egypt. 3(5): 498-503.

Al-Abbassy, L. B. H. (2009). Effect of Foliar Application of Chelated Zinc, Gibberellic Acid and Kinetin on Vegetative Growth of Zaghinia Apricot Seedlings Prunusarmeniaca L. MSc. Thesis, Coll. of Agaric.Mosul Univ., Iraq.p. 91.

Al-Hamadany, N.A.A. (2009). Effect of Gibberellic acid, Kinetin and NPK on seeds germination and seedlings growth Apricot (Prunusarmeniaca L.). M. Sci. Thesis, Coll. of Agric., Mosul Univ., Iraq. p.91.

Al-Khafaji, M. A. (2014). Plant Growth Regulators, Application and Utilization in Horticulture.Bookstore for Printing publishing and translating.University of Baghdad.Iraq.p.348.

Al-Khafaji, M. A. and Muslat, M. M. (1995). Effect of $\mathrm{GA}_{3}$ on fruit set and yield of Citrus Limon 'Burmann' CVS. Mahalee.J. Taqany-Taqania Res. 29: 126-141.

Al-Mousawi, A.A. (2013). Response of two young trees cultivars to N.P.K. fertilization and foliar application of $\mathrm{GA}_{3}$. M. Sci. Thesis, Coll. of Agaric. Univ.ofBaghdad., Iraq.p. 102.

Al-Rawi, K. M. andKhalaf-Alla, A.(1980). Analysis of Experimental Agriculture Disgen.Dar Al-Kutub for Printing and Publishing.Mosul Univ. (In Arabic).

Anjanaw, S. R., Kanpure,R. N., Kachouli, B. K. and Mandloi, D. S. (2013). Effect of plant growth regulators and growth media on seed germination and growth vigour of papaya.Ann. Plant Soil Res., 15(1): 31-34.

Bhandari, A. R. and Randhawa, N. S. (1985).Distribution of available micronulrients in soil of apple orchards in MimachalParadesh.J. Indian Soc. Soil Sci.33:171-174.

Brittenham, G.M. (1994). New Advances in Iron Metabolism, Iron Deficiency and Iron Overload.Current Opinion in Hematology, 1: 549-556.
Clouse, S.D. and Sasse, J.M. (1998).Brassinosteroids:Essential regulators of plant growth anddevelopment. Annu. Rev. Plant Physiol. Plant Mol.Biol., 49: 427-451.

Desouky, I.M, Shaltout, A.D,Haggag, L. F, Fouad, A. A. and Farahat, E. M.M. (2016). Influence of spraying Kalmata and Picual olive trees with $\mathrm{GA}_{3}$ and $\mathrm{ZnSO} 4$ on leaf nutrient status and chlorophyll content. Research Journal of Pharmaceutical, Biological and Chemical Sciences. 7(5):141-150.

Drovnic, C. E., Howell, G. S. and Elore, A. j. (1965). Influence of crop load on photosynthesis and dry mater partitioning at several grapevines II. Seasonal change in single leaf and whole vine photosynthesis. Amer. J. End. Vitic. 46(40): 469-477.

El-Kassas.E., Mahamoud, H.M. and El-Shazly, S.M. (1987).Effect ofcertain micronutrient on the yield and fruit quality of Balady mandarin.Assiut. J. Agric. Sci., 18(4): 235-253.

El-Shenawy, I. E. (2005): Effect of inflorescences thinning spraying of some fertilizers and growth regulators on growth and productivity of Keitt Mango trees. Egypt . J. Appl. Sci., 20 (2): 182-196.

Francis, D andSrrell, D.A. (2001).The interface between the cell cycle and plant growth.Plant Growth Regulation.33 (1): 1-12

Gindia, H. (2003). Physiology of Fruit Trees. Dar Al Arabia for publication and distribution, the Arab Republic of Egypt.p. 471

Goss, J. A. (1973). Physiology of plants and their cells.Pargamonprees.Inc. New York. USA.

Gul, H., Khattak, A.M. and Amin, N.(2006). Accelerating the growth of Araucaria heterophylla seedlings through different gibberellic acid concentrations and nitrogen levels.J. Agric. Biol. Sci., 1: 25-29.

Gyana R. R. and Sunita, S.(2015)Role Of Iron In Plant Growth And Metabolism.Department of Agricultural Biotechnology, College of Agriculture, Orissa University of Agriculture and Technology, Bhubaneswar 751 003, Odisha, India.

Hansch, R. and Mendel, R. R. (2009). Physiological functions of mineral micronutrients $(\mathrm{Cu}, \mathrm{Zn}, \mathrm{Mn}, \mathrm{Fe}, \mathrm{N}, \mathrm{Mo}, \mathrm{B})$ curr. Opin.Plant biol. 12,259.266.

Harshavardhan, A. and Rajasekhar, M. (2012). Effect of pre-sowing seed treatments on seedling growth of jackfruit.(Artocarpusheterophyllus Lam). J. Res. Angrau. 40(4): 87-89

Hassan, H.S.A., Sarrwy, S.M.A. and Mostafa, E.A.M. (2010).Effect of foliar spraying with liquid organic fertilizer, some micronutrients and gibberellins on leaf mineral content, fruitset, yield, fruit quality of 'Hollywood' plum trees. Agriculture and Biology Journal of North America 1(4): 638643.

Kailis, S.G. and Harris, D. (2007).Producing table Effect of Foliar Sprays with Potassium Nitrate and olives. National Library of Australia Cataloguing in Mono-potassium Phosphate on leaf mineral Publication Entry, p: 345.

Marschner, H. (1986). Mineral nutrition of higher plants.Academic press. London, p. 674.

Marschner, H. (1995).Mineral nutrient of higher plants. Second Ed., Academic Press Limited. Harcourt Brace and Company, Publishers, London, p. 347-364.

Morales, F., Abadía, A. andAbadía J. (1994). Iron deficiency induced changes in the photosynthetic pigment composition of field grown pear (Pyruscommunis L.) leaves. Plant, Cell and Environment 17, 1153-1160.

Ramezani, S. and Shekafandeh, A. (2009).Roles of gibberellic acid and zinc sulphate in increasing size and weight of olive fruit. African J. Biotechnology, 8 (24): 6791-679.

Romheld, and Marschner. (1991). Function of micronutrients in plants. In: Mortvedt, p.297-3328.

Rosenvasser, S., S.and Friedman M. H.(2006). Increase in reactive oxygen species (ROS) and insenescence associated gene transcript (SAG) levels during dark induced senescence of Pelargoniumcuttings, and the effect of gibberellic acid. Plant Sci., 170: 873-879.

Samaranayake, P., Peiris, B. and Dssanayake, S. (2012) Effect of excessive ferrous $(\mathrm{Fe} 2+)$ on growth and iron content in rice (Oryzasativa). Int. J. Agri. Biol., 14: 296-298.

SAS Institute, Inc (2000). Statistical analysis system. SAS institute Inc., Cary, NC. USA.

Schmidt, W. (1993). Iron stress-induced redox reactions in bean roots. Physiol. Plantarum, 89: 448-452 
Shaban, A.E.A. (2010). Improving seed germination and seedling growth of some mango rootstocks.American-Eurasian $J$ Agric. \& Environ. Sci., 7(5): 535-541.

Shayal Alalam, A.T.M .(2009). Effect of nitrogen fertilizer and gibberellic, ascorbic acids and liquorice root extract spray on young peach trees CV. Dixie red growth. MSc. Thesis, Coll. of Agaric. Mosul Univ., Iraq. p. 98.

Shayal Alalam, A.T.M.(2013). Effect of Foliar Spray with Seaweed Extract Kelpak40 and Cheleated Iron on the Growth of Loquat Seedling. Mesopotamia Journal of Agriculture. 41( 2) : 39-47.

Shanmugavelu, K. G. (1966). Studies on the effect of plant growth regulator on the seedling of some tree plant species.South Indian Hort., 14: 24-25.

Sen, S. K. and Ghunti, P. (1976).Effect of pre-sowing seed treatment on the germination and seedling growth in papaya. Orissa $J$. Hort., 4: 38-43.

Soest, P. J. V. (2012). Influence of foliar application of some nutrient and gibberellic acid on fruit set, yield, fruit quality and leaf composition of "Anna" apple trees grown in sandy soil.International Journal of Agr.and Env.3 (1):17-23.
Steven, J. M. (1994). Exogenous Gibberellin Effects Biennial Bearing And Fruit Shape Of 'Braeburn' Apple. Newzeland J. Crop HortSci. 22: 343-346.

Taiz, L. and E. Zeiger (2002).Plant physiology.Sinauer Associates, Inc., Sunderland, MA. P: 461-492.

Vasantha, P. T.,Vijendrakumar, R. C.,Guruprasad, T R.,Hanumanthaiah, M. R. and Muttappanavr, R. D. (2014). Studies on influence of growth regulators and nutrient foliar spray on seedling growth of tamarind (Tamarindusindica L.). Asian J. Hort., 9(1): 206-209.

Yang D.S., H.X Guo and J.X.Wang, (2007).Cultivation and Development of Olive in Sichuan, Sichuan Science and Technology Press, Chengdu.

Yousefzadeh, S. and Sabaghnia, N. (2016) (Nano-iron fertilizer effects on some plant traits of dragonhead (Dracocephalummoldavica L.) under different sowing densities). Acta Agri. Slovenica, 107(2): 429-437.

Zuo, Y. and Zhang, F. (2011) Soil and crop management strategies to prevent iron deficiency in crops.Plant Soil, 339: 83-95.

Zocchi, G., De Nisi, P., Dell'Orto, M., Espen, L. and Gallina, P.M. (2007). Iron deficiency differently affects metabolic responses in soybean roots. J. Exp. Bot. 58: 993-1000. 